\title{
KEPUASAN KERJA KARYAWAN DITINJAU DARI PERSEPSI KARYAWAN TERHADAP NEGATIVE EXPRESSED EMOTION PIMPINAN
}

\author{
Meirizki Indah Wulan Ningrum \\ Sus Budiharto
}

Fakultas Psikologi dan Ilmu Sosial Budaya Universitas Islam Indonesia

\begin{abstract}
This reseach was aimed to examine the relation between employee's perceptions on leaders' negative expresssed emotion and work satisfaction. The hypothesis was the more negative employee's perception on leader's expresssed emotion, the lower work satisfaction would be and vice versa. The respondents in this reseach were government officials in Yogyakarta. Data collected using questionaires then analyzed by Spearman Rho technique. The results support the reseach hypothesis which the more positive employee's perception on leader's expresssed emotion, the higher employee's work satisfaction and vice versa $(R=-0,227 p=0,039)$.
\end{abstract}

Keywords: perception on negative expressed emotion of leader, Job satisfaction

Karyawan memiliki peran signifikan dalam perubahan yang dilakukan organisasi. Selain itu, karyawan juga merupakan penggerak utama organisasi agar dapat memenuhi tujuan yang telah ditetapkan (Winardi, 1992). Hubungan saling menguntungkan antara karyawan dan organisasi perlu mendapatkan perhatian secara terusmenerus. Dalam relasi kerja di organisasi, apa yang dirasakan karyawan ketika bekerja patut mendapatkan perhatian dari pihak manajemen. Memahami perasaan karyawan ketika bekerja akan sangat membantu pihak manajemen organisasi dalam menentukan langkah-langkah yang harus ditempuh guna mempertahankan karyawan.

Apa yang dirasakan karyawan ketika bekerja merupakan indikator primer kepuasan kerja. Hal ini sebagaimana disampaikan Spector (Adriansyah, 2004) yang menyatakan bahwa kepuasan kerja berhubungan dengan perasaan seseorang terhadap pekerjaannya dan berkaitan dengan berbagai aspek pekerjaan tersebut. Davis ( M a n g ku n e gar a , 20002 ) ju g a mengungkapkan bahwa kepuasan kerja merupakan perasaan menyokong atau tidak menyokong yang dialami karyawan ketika bekerja. Robbins (Johan, 2002) menyatakan bahwa kepuasan kerja merupakan sikap umum pekerja tentang pekerjaan yang dilakukannya, karena pada umumnya apabila orang membahas tentang sikap pegawai, yang dimaksudkan adalah kepuasan kerja.

Kepuasan kerja yang diperoleh karyawan akan mendatangkan keuntungan baik bagi karyawan tersebut secara pribadi, maupun bagi organisasi. Bagi karyawan, kepuasan yang diperolehnya dalam bekerja akan memberikan implikasi berupa perasaan nyaman ketika bekerja. Kepuasan kerja karyawan akan membawa organisasi pada penghematan biaya produksi karena organisasi tidak perlu mengeluarkan biaya ekstra guna mempertahankan karyawannya. 
Rosa dan Himam (2004) menjelaskan bahwa kepuasan kerja yang tinggi merupakan tanda suatu organisasi dikelola dengan baik dan pada dasarnya merupakan hasil manajemen perilaku yang efektif.

Rendahnya tingkat kepuasan kerja pada karyawan akan memberikan implikasi negatif bagi organisasi. Rosa dan Himam (2004) mengatakan bahwa rendahnya kepuasan kerja merupakan salah satu gejala paling meyakinkan dari rusaknya kondisi organisasi. Rendahnya kepuasan kerja yang terjadi pada karyawan biasanya tersembunyi di belakang aksi-aksi pemogokan liar, pelambanan kerja, mangkir dan terjadinya pergantian pegawai. Gejala-gejala ini merupakan bagian dari keluhan, rendahnya prestasi, rendahnya kualitas produk, penerimaan yang dilakukan pegawai, serta masalah indisipliner (Rosa \& Himam, 2004). Borg dan Riding (Dhanasamsilp dkk, 2006) berpendapat bahwa rendahnya kepuasan kerja karyawan sangat berhubungan dengan perilaku turnover dan kemangkiran kerja. Sedangkan Wexley (As'ad, 1999) mengatakan bahwa salah satu bentuk ketidakpuasan kerja adalah munculnya perasaan frustrasi yang dapat melahirkan perilaku agresif.

Kepuasaan kerja merupakan hal yang sangat penting untuk dipertahankan guna menunjang kehidupan organisasi. Oleh karenanya, seluruh faktor penunjang kepuasaan haruslah memberikan stimulus positif terhadap meningkatnya kepuasaan kerja karyawan. Pada dasarnya terdapat dua faktor yang menunjang kepuasan kerja karyawan. Faktor tersebut terdiri dari faktor intrinsik atau berasal dari diri karyawan dan faktor ekstrinsik atau faktor yang berasal dari luar diri karyawan. Kedua faktor ini akan selalu berdampingan dan memengaruhi kepuasan kerja karyawan.

Salah satu faktor intrinsik yang berasal dari karyawan adalah persepsi. Karyawan akan memperoleh kepuasan kerja dengan mempersepsi apakah ekspektasinya dapat terpenuhi atau tidak dalam organisasi tempatnya bekerja. Salah satu faktor ekstrinsik penunjang kepuasaan kerja adalah pimpinan atau atasan karyawan. Survei majalah Fortune (Marketing Magazine, 2006) menyebutkan bahwa $75 \%$ karyawan menderita karena berada di bawah atasan yang menyebalkan. Junius Lee (Marketing Magazine, 2006) juga mengatakan bahwa atasan yang menyebalkan berpengaruh pada tingkat turnover karyawan. Atasan merupakan alasan utama karyawan untuk tetap bekerja dan berkembang namun atasan jugalah yang menjadi alasan utama karyawan berhenti dari pekerjaannya, membawa pergi pengetahuan, pengalaman, bahkan kliennya.

Seseorang yang menyandang jabatan sebagai pemimpin pada dasarnya memang diberikan kekuasan yang lebih dibandingkan anggota organisasi lainnya, seperti karyawan (Thoha, 2003). Namun kekuasaan inilah yang seringkali membuat jurang pemisah antara pimpinan dan karyawan. Dipucuk pimpinannya, para leader ini seringkali memaksakan setiap keinginan, pendapat, ataupun pemikirannya tanpa mendengarkan masukkan dari bawahannya. Jika ada bawahan yang menolak untuk mengikuti 
keinginannya, para pimpinan cenderung untuk bersikap negatif terhadap karyawan tersebut.

Lee (Marketing Magazine, 2006) mengatakan bahwa para manajer dapat menekan bawahannya lewat berbagai cara. Misalnya dengan mengontrol bawahan secara berlebihan, curiga, terlalu kritis, dan sebagainya. Perlakuan pimpinan terhadap karyawan di atas dengan jelas memberitahukan bahwa pimpinan menolak kehadiran karyawan dalam lingkungan kerjanya, setidaknya para karyawan dapat mempersepsi bahwa kehadirannya ditolak walaupun belum tentu demikian yang dimaksudkan oleh pimpinan.

Goleman, Boyatzis, dan McKee (2004) juga mengatakan bahwa pimpinan yang senang memberikan kritik tanpa solusi dapat menurunkan kepuasan kerja karyawan yang dikritiknya. Gaya kepemimpinan yang demikian dikenal dengan disonan. Gaya ini dapat diterapkan, hanya saja harus diikuti dengan empati yang tinggi terhadap karyawan, meskipun pimpinan tidak sanggup memberikan solusi berdasarkan kritiknya.Sikap spontan yang ditunjukkan pimpinan sering kali menjadi satu sumber tekanan tersendiri bagi karyawan karena disampaikan dengan cara yang tidak tepat. Sikap spontan pimpinan yang penuh tekanan dan cenderung membahayakan kondisi psikis karyawan dalam bekerja inilah yang secara konseptual dikenal sebagai negative negative expressed emotion pimpinan. Sikap pimpinan yang terlalu memproteksi dan terlalu kritis terhadap bawahan menjadi contoh dari negative negative expressed emotion. Negative expressed emotion pimpinan terhadap karyawannya akan memunculkan suatu perasaan tidak nyaman (insecure) dan tidak aman bagi karyawan dalam bekerja jika karyawan tersebut mempersepsi bahwa pimpinannya memang melakukan suatu tindakan yang mencerminkan negative expressed emotion dalam memimpin organisasi.

Karyawan swasta yang tertekan oleh sikap dan perilaku pimpinan memiliki pilihan untuk keluar dari perusahaan atau tidak memperpanjang kontrak kerja demi mengakiri tekanan akibat negative expressed emotion pimpinan tersebut. Namun para karyawan berstatus PNS akan sulit untuk keluar begitu saja dari pekerjaannya karena biasanya status sebagai PNS dipilih oleh sebagian orang sebagai pekerjaan jangka panjang. Sebagian orang biasanya memilih menjadi PNS karena persepsi kerja yang tidak terlalu berat dan kesejahteraan yang cukup terjamin. Namun di luar fasilitas yang diberikan tadi, profesi PNS tidak memiliki banyak pilihan ketika harus berhadapan dengan pimpinan yang memberikan tekanan selama bekerja. Pimpinan yang memberikan tekanan lewat sikap, cara bicara, maupun tingkah laku ini menjadi salah satu sumber hambatan bagi tercapainya kepuasan kerja. Pada akhirnya, PNS yang tidak memperoleh kepuasan kerja menunjukkan kinerja lamban dan acuh tak acuh terhadap tugas yang menjadi tanggung jawabnya.

Uraian dan beberapa fakta yang diungkapkan di atas, menjadi dasar bagi peneliti untuk memformulasikan hipotesis penelitian bahwa ada hubungan antara 
persepsi karyawan terhadap negative expressed emotion pimpinan dan tingkat kepuasan kerja karyawan tersebut, dalam hal ini karyawan yang bertatus sebagai PNS.

\section{METODE PENELITIAN}

\section{Responden Penelitian}

Responden penelitian ini adalah PNS

Dinas KIMPRASWIL propinsi D.I. Yogyakarta dengan karakteristik pendidikan minimal SMU/SMK sederajat dan memiliki atasan langsung.

\section{Metode Pengumpulan Data}

Alat ukur yang digunakan dalam penelitian dibuat sendiri oleh peneliti dan terdiri atas dua jenis, yaitu skala kepuasan kerja dan skala persepsi karyawan terhadap negative expressed emotion pimpinan. Skala Kepuasan Kerja dibuat berdasarkan aspek yang diungkapkan oleh Smith, Kendall, dan Hulin (Prabowo, 2004), Rosa dan Himam (2004), dan Kusuma (1999). Skala ini terdiri atas 40 butir pernyataan. Setiap pernyataan mempunyai alternatif jawaban yang bergerak dari "Sangat Puas" sampai "Tidak Pernah merasakan Puas". Pemberian skor bergerak dari 5 untuk sangat puas sampai pada 1 untuk skor tidak pernah merasa puas. Skala persepsi karyawan terhadap negative expressed emotion pimpinan disusun berdasarkan aspek-aspek expressed emotion yang diadaptasi dalam konteks hubungan atasan dan bawahan. Adapun aspek expressed emotion yang digunakan diambil dari hasil penelitian Leff dan Vaugh (Hasanat, 2004). Jumlah aitem dalam skala ini adalah sebanyak 34 aitem. Setiap pernyataan mempunyai alternatif jawaban dari tidak pernah mengalami hingga sering mengalami. Pemberian skor pada setiap pertanyaan atau pernyataan bergerak dari 1 hingga 5 untuk jawaban tidak pernah mengalami hingga sering mengalami.

\section{Teknik Analisis Data}

Teknik analisis data yang digunakan dalam penelitian ini adalah uji korelasi Spearman. Tujuan analisis ini adalah untuk mengetahui signifikansi hubungan antara variabel persepsi terhadap negative expressed emotion pimpinan dan kepuasan kerja karyawan.

\section{HASIL PENELITIAN}

Hasil Uji Asumsi

Uji normalitas dalam peelitian ini dilakukan dengan menggunakan teknik one sample kolmogorov smirnov test. Berdasarkan hasil analisis data, diperoleh koefisien $\mathrm{K}-\mathrm{SZ}=0,894$ dengan $\mathrm{p}=0,402$ $(\mathrm{p}>0,05)$ untuk variabel kepuasan kerja dan $\mathrm{K}-\mathrm{SZ}=1,346$ dengan $\mathrm{p}=0,053(\mathrm{p}>0,05)$ untuk variabel persepsi terhadap negative expressed emotion pada karyawan. Hasil uji normalitas tersebut menunjukkan bahwa data kepuasan kerja dan persepsi karyawan terhadap negative expressed emotion pimpinan memiliki distribusi yang normal.Berdasarkan uji linieritas diperoleh nilai $F=2,894$ dengan $p=0,099$. Hasil tersebut menunjukkan bahwa hubungan antara kepuasan kerja dan persepsi karyawan terhadap negative expressed emotion pimpinan, bersifat tidak linier. 


\section{Hasil Uji Hipotesis}

Mengacu pada hasil uji normalitas dan linieritas data penelitian, maka digunakan teknik analisis spearman rho untuk mengetahui hubungan antara kedua variabel penelitian. Berdasarkan pengujian dengan menggunakan analisis Spearman's rho diperoleh hasil koefisien korelasi $(\mathrm{R})=$ 0,227 dengan $p=0,039(p<0.05)$.Hal ini menunjukkan bahwa ada hubungan negatif yang signifikan antara persepsi karyawan terhadap negative expressed emotion pimpinan dan kepuasan kerja.

\section{PEMBAHASAN}

Penelitian ini bertujuan untuk menguji hipotesis tentang adanya hubungan negatif antara persepsi karyawan terhadap negative expressed emotion pimpinan dan kepuasan kerja. Berdasarkan analisis deskriptif data penelitian diketahui bahwa nilai rata-rata skor kepuasan kerja (mean empirik=128,4918) lebih tinggi dari rata-rata skor hipotetiknya (mean hipotetik=120). Data tersebut menunjukkan bahwa karyawan memiliki kepuasan kerja lebih besar dari rata-rata yang diperkirakan. Secara lebih spesifik, kepuasan kerja yang dimunculkan oleh responden sebagian besar berada pada tingkatan tinggi $(42,622 \%)$ dan sedang $(40,983 \%)$.

Pada data persepsi karyawan terhadap negative expressed emotion pimpinan, karyawan memiliki rata-rata skor (mean empirik $=53,9180$ ) yang lebih rendah dari rata-rata skor hipotetik (mean hipotetik = 102). Hal tersebut menunjukkan bahwa persepsi terhadap negative expressed emotion pimpinan pada responden berada di bawah rata-rata yang diperkirakan. Lebih dari setengah $(67,213 \%)$ dari responden memiliki persepsi terhadap negative expressed emotion pimpinan yang sangat rendah, sedangkan 24,590\% karyawan responden memiliki tingkat persepsi terhadap negative expressed emotion pimpinan yang rendah.

Hasil analisis data dalam penelitian ini menunjukkan bahwa hipotesis tersebut terbukti secara signifikan. Hasil ini ditunjukkan dengan nilai koefisien korelasi yang diperoleh $(r=-0,277$ dan $p=0,039)$. Nilai koefisien korelasi yang negatif menunjukkan hubungan negatif antara persepsi karyawan terhadap negative expressed emotion pimpinan dan kepuasan kerja, dan nilai $\mathrm{p}$ sebesar $0,039(\mathrm{p}<0,05)$ menunjukkan bahwa terdapat hubungan tersebut signifikan.

Hasil riset Bavendam Research Incorporated pada tahun 2000 (Prabowo, 2004) menjelaskan bahwa kepemimpinan (leadership) merupakan salah satu faktor yang memengaruhi kepuasan kerja karyawan disamping faktor lain seperti opportunity, tingkat stress, work standard, fair reward, dan adequate authority. Hasil penelitian ini relevan dengan temuan Bavendam Research Incorporated. Hasil penelitian ini menjelaskan bahwa kepuasaan kerja karyawan akan dipengaruhi oleh bagaimana karyawan tersebut memandang dan menginterpretasikan sikap dan tingkah laku pimpinannya dalam mengarahkan dan memimpin selama proses kerja di organisasi. Hubungan buruk antara pimpinan 
dan karyawan akan memengaruhi kepuasan kerja karyawan. Cara pandang karyawan terhadap sikap dan tingkah laku pimpinannya akan memengaruhi perasaannya ketika bekerja dan berinteraksi dengan banyak pihak, termasuk dengan atasannya itu sendiri, rekan kerja bahkan patner kerja lainnya. Caugemi dan Claypool (Rosa \& Himam, 2004) menjelaskan bahwa kepuasan kerja akan menyangkut cara kerja karyawan dalam menyesuaikan diri dengan kondisi dan situasi kerja.

Penyesuaian diri tersebut akan berhubungan dengan interaksi sosial, baik antar sesama karyawan, dengan atasan, maupun antar karyawan yang berbeda jenis pekerjaannya. Oleh karena itu, negative expressed emotion yang ditunjukkan pimpinan dan dipersepsi oleh karyawan merupakan suatu sumber tekanan yang menimbulkan stres tersendiri bagi karyawan dan dapat memberikan dampak negatif pada kepuasan kerja karyawan. Namun, jika karyawan mempersepsi negative expressed emotion yang ditunjukan pimpinannya seminimal mungkin, maka tingkat kepuasan kerja yang tinggi akan menjadi lebih mudah untuk diperoleh.

Hadi (Anorga, 2001) menyatakan bahwa kepuasan kerja pada dasarnya merupakan security feeling (rasa aman) dalam bekerja yang memiliki dua segi yaitu segi sosial ekonomi serta segi sosial psikologi. Negative expressed emotion pimpinan yang dipersepsi oleh karyawan termasuk dalam segi sosial psikologi yang akan memengaruhi kepuasan kerjanya. Sebagai seorang pegawai negeri sipil, responden boleh jadi telah merasa cukup aman dengan gaji perbulan dan berbagai tunjangan yang diperolehnya. Namun berdasarkan penelitian kali ini, peran segi sosial-ekonomi juga didukung oleh peran sosial-psikologis dalam menciptakan kepuasan kerja pada PNS.

Dari sisi sosial-ekonomi, gaji tetap dan jenjang promosi serta tunjangan pensiun tentu saja memberikan rasa aman (secure) bagi PNS tersebut. Rasa aman dalam bekerja yang diperoleh para karyawan melalui serangkaian tunjangan dari segi sosialekonomi ini yang menentukan tingkat kepuasan kerja yang dirasakan. Sedangkan dari sisi sosial-psikologis, menurut penelitian ini sejumlah $67,213 \%$ responden memiliki tingkat persepsi terhadap negative expressed emotion pimpinan pada kategori sangat rendah. Hal ini dapat memberikan gambaran bahwa praktik negative expressed emotion pimpinan hampir tidak dirasakan oleh sebagian besar karyawan. Beberapa sifat pimpinan dalam berinteraksi dengan karyawan yang tercangkup dalam istilah negative expressed emotion dapat dikatakan terbukti berpengaruh atau dipersepsi secara negatif oleh responden. Hal ini berarti dari sisi pengawasan dan hubungan antar karyawan dan atasan dalam lingkup interaksi kerja ditubuh Dinas KIMPRASWIL propinsi D.I. Yogyakarta tidak terjadi suatu hubungan buruk yang memberikan dampak tidak tercapainya kepuasan kerja karyawannya.

Analisis kepuasan kerja karyawan melalui teori model dari Howell dan Dipboye (Munandar, 2001) menunjukkan bahwa kepuasan kerja karyawan sangat dipengaruhi 
oleh kondisi kerjanya. Kondisi kerja karyawan yang mempersepsi negative expressed emotion pimpinan pada kontinum rendah mengindikasikan kondisi kerja yang baik dan tidak menimbulkan tekanan yang mengganggu, sehingga para karyawan merasa puas dengan pekerjaannya.

Salah satu faktor yang menyebabkan ketidakpuasan dalam bekerja adalah hubungan pribadi (personal relation) antara atasan dan bawahan (Sigit, 2003). Rendahnya persepsi karyawan terhadap negative expressed emotion pimpinan $(67,213 \%)$ yang terungkap pada penelitian ini juga membuktikan bahwa pada responden, sudah terjalin hubungan yang baik antara pimpinan dan karyawan sehingga kepuasan kerja yang cenderung tinggi dapat diperoleh karyawan.

Analisis tentang kepuasan kerja tidak akan berhenti pada satu titik saja. Seperti yang diketahui, kepuasan kerja merupakan masalah dinamis yang membutuhkan perhatian terus-menerus dari organisasi, baik organisasi publik maupun swasta. Banyak hal yang perlu ditelaah untuk membahas kepuasan kerja secara lebih dalam dan mendetail. Beberapa faktor seperti latar belakang budaya, jenis kelamin, usia dan orientasi kerja yang cenderung diabaikan pada penelitian ini menjadi satu kelemahan tersendiri.

\section{SIMPULAN}

Penelitian yang dilakukan kali ini menyimpulkan beberapa hal penting yang patut untuk diperhatikan, di antaranya adalah sebagai berikut:
1. Persepsi karyawan terhadap negative expressed emotion pimpinan berkolerasi negatif secara signifikan terhadap kepuasan kerja respondn, yaitu dengan nilai koefisien korelasi $(R)=-0,277$ dan taraf signifikansi $(\mathrm{p})=0,039(\mathrm{p}<0,05)$. Dapat dikatakan terdapat hubungan negatif yang signifikan antara persepsi karyawan terhadap negative expressed emotion pimpinan dan kepuasan kerja responden.

2. Sumbangan efektif yang diberikan variabel persepsi karyawan terhadap negative expressed emotion pimpinan terhadap kepuasan kerja karyawan tergolong kecil yaitu sekitar 7,67\%.

\section{DAFTAR PUSTAKA}

Adriansyah, A. (2004). Peran Budaya Organisasi dalam Peningkatan Unjuk Kerja Perusahaan: Persepsi Dua Suku Bangsa Terhadap Gaya Kepemimpinan Atasan Dalam Rangka Kepuasan Kerja. Jakarta: Bagian Psikologi Industri dan Organisasi Fakultas Psikologi Universitas Indonesia

Anoraga, P. (2005). Psikologi Kerja. Jakarta: Rineka Cipta

As'ad, M.(1999). Seri Ilmu Sumber Daya Manusia: Psikologi Industri. Yogyakarta: Liberty

Dhanasamsilp, P; Johnson, H ; Chaipopirutana, S. (2006). An Investigation of Work Values and Resulting Job satisfaction in Relationship to Two Work Roles in Thailand.The Buisness Review, 5, 161-171 
Goleman, D; Boyatzis, R; \& Mckee, A $\left(\begin{array}{llll}2 & 0 & 0 & 4\end{array}\right)$. P $\quad r \quad i \quad m \quad a l$ Leadership:Kepemimpinan Berdasarkan Kecerdasan Emosi. Jakarta: PT. Gramedia Pustaka Utama.

Hasanat, N.U. (2004). Negative expressed emotion pada Keluarga Penderita Gangguan Jiwa. Buletin Psikologi (Fakultas Psikologi UGM), 2, 85-91

Johan, R. (2002). Kepuasan Kerja Karyawan dalam Lingkungan Institusi Pendidikan. Jurnal Pendidikan Penabur, 1,6-31

Kusuma, H. (1999). The Impact Of Etichal Climate On Job Satisfaction Of Academic Staff. Sinergi, 2(2), 217228

Mangkunegara, A. (2002). Manajemen Sumber Daya Perusahaan. Bandung: PT. Remaja Rosdakarya.

Munandar, A. S. (2001). Psikologi Industri dan Organisasi. Jakarta:UI-Press
Prabowo, S. (2004). Pengaruh Kepuasan Kerja Dan Komitmen Organisasi Terhadap Keaktifan gugus Kendali Mutu Pada Karyawan Pabrik. Jakarta: Bagian Psikologi Industri dan Organisasi Fakultas Psikologi Universitas Indonesia

Rosa, M. \& Himam, F. (2004). Hubungan Antara Persepsi terhadap Sense Of Humor Pemimpin dan Kepuasan Kerja Karyawan. Jurnal Psikologi (Fakultas Psikologi UGM), 2, 116129.

Sigit, S. (2003). Perilaku Organisasi. Yogyakarta: Bagian Penerbitan Fakultas Ekonomi Universitas Sarjanawiyata Taman Siswa

Thoha, M. (2003). Kepemimpinan dalam Manajemen: Suatu Pendekatan Perilaku. Jakarta: Rajawali Press

Winardi, S.E. (1992). Manajemen Perilaku Organisasi. Bandung: Penerbit PT. Citra Aditya Bakti. 